\title{
Determinant of Student Decisions in Choosing Diploma Study Program at Vocational College
}

\author{
Amir Hamzah \\ Program Studi Manajemen Administrasi - ASM Lepisi Tangerang \\ amir@lepisi.ac.id \\ Tito Prayitno \\ Program Studi Manajemen Administrasi - ASM Lepisi Tangerang \\ prayitnotito@gmail.com
}

Received: 26 April 2021; Revised: 16 July 2021; Accepted: 13 August 2021 DOI: http://dx.doi.org/10.37905/aksara.7.3.1029-1044.2021

\begin{abstract}
The requirements in entering the world of work today demand professional skills and abilities according to the needs of the organization. Therefore, effective marketing strategies become important for vocational colleges to get prospective students. There are several studies that examine the factors that influence students' decisions in choosing a college, but research focusing on vocational college research is still very limited. This study aims to analyze the determinants that influence students' decisions in choosing a course of study at a Vocational College. This study was conducted by an online survey of 158 respondents who were studying at three Vocational Universities in Banten Province, namely ASM Lepisi, Politeknik LP3I Jakarta Tangerang Campus, and Politeknik PGRI Banten. Analyze the data using Partial Least Square Structural Equation Modeling (PLS-SEM). Finally, the author expects the empirical results of this study to be useful as a reference for marketing practitioners of Vocational Universities in West Java and Banten, in particular and Indonesia in general.
\end{abstract}

Keywords: Quality Perception, Motivation, Social Media Marketing, Value

Perception, and Student Decision.

\section{INTRODUCTION}

The requirements of the world of work towards skilled and competent human resources raise public awareness to continue education to a higher level of education. Large companies today need human resources that have a higher education background, in order to improve the competitiveness of the organization. This makes the community's animo to continue their education to college or university increasing every year. But the number of universities in West Java and Banten is very much and always increases over time. Based on data obtained from the Higher Education Database of the Ministry of Research, Technology, and Higher Education of the Republic of Indonesia. There are currently 456 universities (https://www.lldikti4.or.id) in West Java and Banten. With the number of universities, making competition between universities increasingly tight, especially for Vocational Colleges. Universities are institutions that need to determine segmentation or consumers that can be reached or served effectively by marketers. To 
win competition and gain students in student admissions, "universities need to analyze consumer behavior and determine clear target markets so that they can later analyze market opportunities and competitors, and ultimately be able to implement different promotions. from what other institutions do" (Handayani, 2019). According to Rudhumbu, N., Tirumalai, A., Kumari (2017), "analyzing the factors that influence the choice of college students should be treated as an important component in improving the institution's marketing strategy plan for new student enrollment", as it "has great benefits for higher education institutions as they try to attract more students in today's competitive world" (Ilgan, A., Ataman, O., Ugurlu, F., Yurdunkulu, 2018).

An understanding of consumer behavior helps marketers to understand how consumers think, feel and choose from a variety of alternatives such as products, services, and how consumers are influenced by their environment, reference groups, families, and salespeople, and so on. Consumer behavior is influenced by cultural, social, personal and psychological factors. There are several factors that influence consumers in decision making. Some literature and research mention some of the rare factors that influence consumer decisions, including "perceptions of perceived quality and value"(Zeithaml, V., 1988), "motivation" (Prebensen et al., 2013) and "social media marketing" (Nurohman, Y.A., Qurniawati, 2018). Based on the explanation above, this study aims to examine the determinants that influence students' decision to choose a course in Vocational College.

\section{RESEARCH METHODS}

This research analyzes the determinants that influence students' decisions in choosing a course of study at Vocational College. In this study there are four free variables namely "quality perception" $\left(\mathrm{X}_{1}\right)$, "motivation" $\left(\mathrm{X}_{2}\right)$, "social media marketing" $\left(\mathrm{X}_{3}\right)$, and "trust" $\left(\mathrm{X}_{4}\right)$, as well as two bound variables namely "value perception" $\left(\mathrm{Y}_{1}\right)$ and "student decision" $\left(\mathrm{Y}_{2}\right)$. The tool used to analyze the data in this study is SmartPLS 3.0. In this study, the population used was students who were studying at vocational colleges.

The technique used to determine samples in this study is non-probability sampling. The principle of selection in this method is to select each sample without providing equal opportunities for each element or member of the population to be sampled. In addition, this study also uses purposive sampling techniques. The respondents' provisions in this study were based on the following characteristics: (1) respondents were students of Vocational Colleges in West Java and Banten, namely ASM Lepisi, Politeknik LP3I Jakarta Tangerang Campus, and Politeknik PGRI Banten, and (2) respondents were students. who chooses a Diploma 3 (three) program at a Vocational College. This study used the Likert scale created by into five alternative answers for each variable as a measurement scale, i.e. ' 1 = strongly disagree', ' 2 = disagree', ' 3 = somewhat disagree', ' 4 $=$ agree', ' 5 = strongly agree'.

\section{LIBRARY REVIEW AND HYPOTHESES \\ Perceived Quality and Value}

Quality and Value Perceived quality is "consumer assessment of the superiority of a product" (Zeithaml, V., 1988). "The perception of high quality shows that consumers have found the difference and excellence of a product or service with similar products offered by other companies after a long evaluation" (Kurnianto, 2015). Zeithaml, V. (1988) in his research explains the theory of the "Means-End Model" which states that 
"perception of quality can directly affect the perceived value". When consumers feel that the quality of the products purchased is in line with their expectations, it will increase the perceived value. The better the quality of products provided by the company that can be felt by customers, the better the value felt by consumers.

In addition, according to Chen et al. (2017), "quality perception has an important role in the process of perceived value formation, which indicates that the quality of service will increase the value and benefits felt by consumers, thus positively affecting their buying intentions". Products or services that have good quality indicate that the product or service meets consumer expectations. When a product or service can meet customer expectations, then the consumer perceives that a product or service has a high value. Based on the above statement, it can be formulated hypotheses as follows:

$\mathrm{H}_{1}$ : Perceived quality positively affects the perceived value.

\section{Perceived Quality and Student Decisions}

Perceived quality encourages consumers to "consider and purchase products or services from a particular brand" (Kandasamy, 2014). It is based on a person's behavior in making decisions about what he wants that relates to perception. "Perception will relate to a person's behavior in making decisions about what he wants, including purchasing decisions" (Harjati \& Sabu, 2014). The increasing consumer awareness lately makes them just want to buy or pay for a well-known and quality brand or product. So, it is important for universities to create a perception of superior quality in the hearts of the community, especially prospective students. According to Nguyen (2014), "quality perception takes into account the subjectivity that is the consumer's evaluation of a product or service and the assessment based on several attributes". Based on the above statement, it can be formulated hypotheses as follows:

$\mathrm{H}_{2}$ : Perceived quality positively affects students' decisions in choosing a study program at vocational colleges.

\section{Motivation and Perceived Value}

In consumer behavior, motivation plays an important role in consumer decision making. According to Ryan, R. M. D. \& Edward (2000) "motivation can be distinguished into two types, namely intrinsic motivation and extrinsic motivation". Intrinsic motivation is the motivation to get challenges, pleasures, interests and satisfaction without any outside encouragement. While extrinsic motivation is the motivation that is done because of external demands. Motivation, both intrinsic and extrinsic will encourage a person to act, where the action is also based on values that suit him. Several studies have found a link between motivation and perceived value (Prebensen et al., 2013). Based on the description above, it can be formulated hypotheses as follows:

$\mathrm{H}_{3}$ : Motivation positively affects the perceived value.

\section{Motivations and Student Decisions}

Decisions taken by consumers are part of consumer behavior, where stable decisions are usually influenced by a variety of factors. Motivation is one of the factors that influence consumers to make decisions. Similarly, with students who will choose a college to continue their studies, this is influenced by their motivation. According to (Wahyuni, 2008) states that "the motivation of purchase is the consideration and influence 
that encourages people to make purchases". This information is supported by the results of several studies that describe the relationship between motivation and consumer decisions. Based on the above statement, it can be formulated hypotheses as follows:

$\mathrm{H}_{4}$ : Motivation positively affects students' decisions in choosing a study program at vocational colleges.

\section{Social Media Marketing and Perceived Value}

Today, "the internet has changed the way conventional human interactions have in the past and also created a new bridge for communication" (S. C. Chen \& Lin, 2019). The rapid development of information technology affects people's behavior in communicating, as well as the way they seek and obtain information. Many organizations or companies utilize this technology through social media as a means of advertising and marketing.

With social media, organizations and companies seek to influence consumers, by educating the market about the value and excellence they offer. Several studies have shown results of "the impact of social media marketing on perceived value" (S. C. Chen \& Lin, 2019) in his research found that "social media marketing has a positive impact on perceived value". Meanwhile, in the results of research conducted by Serawati (2019) and Khan (2019) stated that "social media marketing has an influence on value awareness". Based on the above statement, it can be formulated hypotheses as follows:

$\mathrm{H}_{5}$ : Social media marketing positively affects the perceived value.

\section{Social Media Marketing and Student Decisions}

According to Lusia, A., Suciati, P., Setiowati (2016), "the role of social media is very important for college marketing strategies". Based on the results of the study that stated that from some marketing stimuli conducted by a college found that the biggest factor influenced the decision of students in choosing a course of study in college is social media. . Regarding "marketing practices, social media plays a role in a variety of ways, such as improving customer service, maintaining customer relationships, informing consumers about the benefits of a product or service, promoting related brands or special offers, developing new products, or influencing brand attitudes" (Tuten, T. S., Michael, 2017). It will also affect a consumer's decision to buy or use a product or service.

In the current era, marketing practices through social media began to develop and used as a means of marketing to promote the "brand" of a company or organization. Universities certainly need to use social media as a marketing tool, so as to influence the decisions of prospective students in choosing it. Digital marketing in colleges is considered very important because universities face stiff competition. Therefore, it is important for them to understand how to attract students and how to market their institutions. Some studies support the above argument that shows the results that there is an influence of social media marketing on consumer decisions (Nurohman, Y.A., Qurniawati, 2018). Based on the above statement, it can be formulated hypotheses as follows:

$\mathrm{H}_{6}$ : Social Media Marketing positively affects students' decisions in choosing programs at Vocational Colleges. 


\section{Trust and Perceived Values}

Consumer behavior that adheres to religious values will also influence their behavior in the decision to purchase a product or service. According to Fauzi, W. I. M., Nazlida, M., Sany, S. M. Y., Rushamie (2016), consumers have attitudes and motivations developed with the values of trust they have when buying a product or using a service. In this case, the more religious a consumer will be the more obedient to religious values, which has an impact on the way consumers view a product or service that is not only to meet their needs, but also influenced by religious motives. Thus, trust will affect the perception of consumer value. Research that discusses the influence of trust on perceived values is very limited. However, there are studies that support the arguments that have been put forward before. Research conducted by Wahyuni (2008), found that trust positively affects the value felt by customers. Based on the above statement, it can be formulated hypotheses as follows:

$\mathrm{H}_{7}$ : Trust positively affects the perceived value.

\section{Trust and Student Decisions}

In consumer behavior, trust also influences purchasing behavior through the underlying sub-culture. The dimension of trust (intrapersonal and interpersonal) has significant possibilities in predicting certain aspects of consumer spending orientation. This suggests that those with high confidence tend to be less impulsive in making purchasing decisions. Similarly, in the decision-making to choose a university chosen by students, students who have a relatively high tendency to trust will choose a university that has the nuances or image it believes in, or at least has the same values as it has. The results of several studies show a relationship between trust and consumer decisions (Ilgan, A., Ataman, O., Ugurlu, F., Yurdunkulu, 2018), although research that discusses the influence of trust in the decision to choose higher education institutions is still very limited. Based on the above statement, it can be formulated hypotheses as follows:

$\mathrm{H}_{8}$ : Trust positively affects students' decisions in choosing a course of study at vocational colleges.

\section{Perceived Value and Student Decisions}

Consumer decision is a process that has stages or levels, where this process starts from the introduction of problems, until it ends in post-purchase behavior. In this decision-making process, towards the search for information and evaluation of alternatives, where consumers will compare a product or service from various brands, which will then choose the product or service in accordance with the perception of the expected value, which is the most profitable, with the minimum sacrifice. According to Zeithaml, V. (1988), the perceived value is an overall consumer assessment of the usefulness of a product based on perceptions of what is received and what is given, which is based on a comparison between benefits and sacrifices. Similarly, for prospective students who want to apply to college one of the considerations is how much profit will be earned when choosing the college, and how much sacrifice should be spent. Some researchers tried to analyze the relationship between perceived value and purchasing decisions, and then found positive relationship results between the two $(\mathrm{H}$. S. Chen et al., 2017). Based on the above statement, it can be formulated hypotheses as follows:

$\mathrm{H}_{9}$ : Perception Value positively affects students' decisions in choosing a 
course of study at Vocational College.

\section{RESEARCH FRAMEWORK}

After conducting previous research studies and formulating hypotheses, a research theory framework was designed to determine what factors influenced students' decisions in choosing a course in Vocational College. Based on the development of the hypothesis outlined above, a research framework can be created as a model:

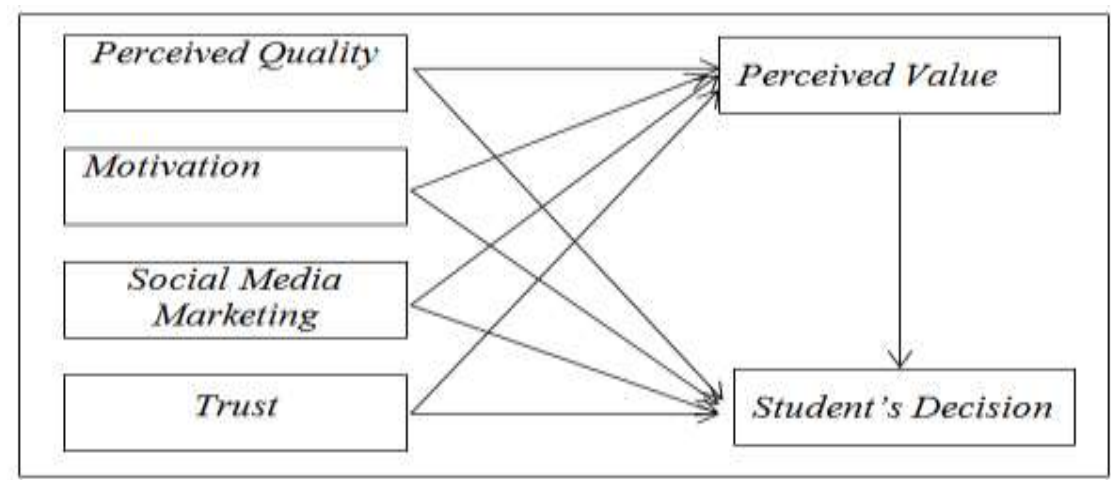

Figure 1. Research Framework

Source: Secondary data processed (2021)

\section{DATA ANALYSIS}

The number of respondents in this study was 184 people, with details of 118 female respondents or $64.1 \%$, while male respondents amounted to 66 people or $35.9 \%$. Furthermore, the respondents were selected and only selected who met the criteria, so that the remaining respondents who were sampled were 158 respondents.

\section{Outer Model Evaluation}

Evaluation of the Outer Model is performed to determine the results of validity and reliability tests. This measurement model shows how a manifest variable or indicator represents a latent variable to be measured. The stages in the Outer Model evaluation can be divided into two, namely the construction validity test which includes the validity of the convergent and discriminatory validity, and the reliability test that includes composite reliability and Cronbach' alpha.

Convergent validity tests are used to validate latent variable indicators assessed based on loading factors. The indicator can be said to be valid if it has a loading factor value $>0.7$. But the loading factor value $>0.6$ is still acceptable, and another criterion is that each latent variable must have an AVE value > 0.5 (Ghozali, I., Latan, 2015). In this study, some indicators have a loading factor value of $<0.6$ so it should be removed from the model. The final result of the loading factor value of each indicator is as follows. 
Table 1. Convergent Validity Test with Loading Factor

\begin{tabular}{|c|c|c|c|}
\hline Variabel & Indicator & Loading Factor & Explanation \\
\hline \multirow[t]{5}{*}{ Perceived Quality } & PQ1 & 0.718 & Valid \\
\hline & PQ2 & 0.774 & Valid \\
\hline & PQ্3 & 0.734 & Valid \\
\hline & PQप4 & 0.748 & Valid \\
\hline & PQ் & 0.821 & Valid \\
\hline \multirow{6}{*}{ Motivation } & $\mathrm{MI4}$ & 0.721 & Valid \\
\hline & MIS & 0.648 & Valid \\
\hline & $\mathrm{M4}$ & 0.849 & Valid \\
\hline & $\mathrm{MS}$ & 0.761 & Valid \\
\hline & $\mathrm{M} 6$ & 0.852 & Valid \\
\hline & $\mathrm{M} 7$ & 0.761 & Valid \\
\hline \multirow{9}{*}{$\begin{array}{l}\text { Social Media } \\
\text { Marketing }\end{array}$} & SMMI & 0.741 & Valid \\
\hline & SMM2 & 0.806 & Valid \\
\hline & SMMB & 0.669 & Valid \\
\hline & SMM4 & 0.697 & Valid \\
\hline & SMMS & 0.792 & Valid \\
\hline & SMM6 & 0.694 & Valid \\
\hline & SMMT & 0.726 & Valid \\
\hline & SMMP & 0.673 & Valid \\
\hline & SMMY & 0.621 & Valid \\
\hline \multirow[t]{8}{*}{ Trust } & TI & 0.885 & Valid \\
\hline & $\mathrm{T} 2$ & 0.894 & Valid \\
\hline & T3 & 0.951 & Valid \\
\hline & $\mathrm{T4}$ & 0.902 & Valid \\
\hline & T5 & 0.905 & Valid \\
\hline & T6 & 0.858 & Valid \\
\hline & T8 & 0.827 & Valid \\
\hline & T9 & 0.746 & Valid \\
\hline \multirow[t]{6}{*}{ Percerved Value } & PVI & 0.764 & Valid \\
\hline & PV2 & 0.742 & Valid \\
\hline & PV3 & 0.829 & Valid \\
\hline & PV4 & 0.776 & Valid \\
\hline & PVS & 0.652 & Valid \\
\hline & PV6 & 0.707 & Valid \\
\hline \multirow{4}{*}{ Student's Decision } & SD2 & 0.872 & Valid \\
\hline & SD3 & 0.802 & Valid \\
\hline & SD4 & 0.870 & Valid \\
\hline & SDS & 0.808 & Valid \\
\hline
\end{tabular}

Source: Primary data processed (2021)

The recommended AVE value should be above 0.5 (Ghozali, I., Latan, 2015). Evaluation results based on AVE values in latent variables in this study can be seen in the following table that shows the value for each construction is higher than the threshold value of 0.5 .

Table 2. Reliability Test and AVE Test of outer model

\begin{tabular}{|c|c|c|c|c|}
\hline & $\begin{array}{c}\text { Cronbach's } \\
\text { Alpha }\end{array}$ & rho_A & $\begin{array}{c}\text { Composite } \\
\text { Reliability }\end{array}$ & $\begin{array}{c}\text { Average Variance } \\
\text { Extracted (AVE) }\end{array}$ \\
\hline Student's Decision & 0.860 & 0.865 & 0.905 & 0.704 \\
\hline Motivation & 0.859 & 0.863 & 0.896 & 0.591 \\
\hline Perceived Quality & 0.817 & 0.821 & 0.872 & 0.578 \\
\hline Perceived Value & 0.840 & 0.846 & 0.883 & 0.558 \\
\hline Trust & 0.955 & 0.970 & 0.962 & 0.762 \\
\hline $\begin{array}{c}\text { Social Media } \\
\text { Marketing }\end{array}$ & 0.880 & 0.891 & 0.904 & 0.512 \\
\hline
\end{tabular}

Source: Primary data processed (2021) 
The next evaluation is the validity of the discriminant. The evaluation is to look at the cross loading value on the indicator of each intended construction and compare it with the cross loading value on other construction indicators, with the factor loading criteria of each scale item for the specified latent construction should be higher than its loading on other constructions, and also the value should be greater than 0.7 . The cross loading value in this study can be seen in the following table.

Table 3. Factor Loadings and Cross Loadings of outer models

\begin{tabular}{|c|c|c|c|c|c|c|}
\hline & $\begin{array}{l}\text { Students' } \\
\text { Decision }\end{array}$ & Motivation & $\begin{array}{c}\text { Perceived } \\
\text { Quality }\end{array}$ & $\begin{array}{c}\text { Perceived } \\
\text { Value }\end{array}$ & Trust & $\begin{array}{c}\text { SocialMedia } \\
\text { Marketing }\end{array}$ \\
\hline SD2 & 0.872 & 0.472 & 0.294 & 0.471 & 0.080 & 0.336 \\
\hline SD3 & 0.802 & 0.486 & 0.262 & 0.404 & -0.029 & 0.370 \\
\hline SD4 & 0.870 & 0.468 & 0.345 & 0.536 & 0.056 & 0.358 \\
\hline SD5 & 0.808 & 0.500 & 0.526 & 0.652 & 0.156 & 0.368 \\
\hline M14 & 0.446 & 0.721 & 0.228 & 0.377 & -0.089 & 0.334 \\
\hline M15 & 0.435 & 0.648 & 0.231 & 0.357 & -0.012 & 0.274 \\
\hline M4 & 0.428 & 0.849 & 0.296 & 0.452 & 0.082 & 0.302 \\
\hline M5 & 0.445 & 0.761 & 0.275 & 0.453 & 0.179 & 0.269 \\
\hline M6 & 0.481 & 0.852 & 0.309 & 0.465 & 0.042 & 0.343 \\
\hline M7 & 0.415 & 0.761 & 0.182 & 0.397 & -0.011 & 0.242 \\
\hline PQ1 & 0.280 & 0.160 & 0.718 & 0.517 & 0.231 & 0.232 \\
\hline PQ2 & 0.296 & 0.158 & 0.774 & 0.506 & 0.244 & 0.374 \\
\hline PQ3 & 0.409 & 0.442 & 0.734 & 0.474 & 0.175 & 0.381 \\
\hline PQ4 & 0.274 & 0.249 & 0.748 & 0.461 & 0.190 & 0.333 \\
\hline PQ5 & 0.389 & 0.246 & 0.821 & 0.555 & 0.231 & 0.274 \\
\hline PV1 & 0.458 & 0.433 & 0.504 & 0.764 & 0.253 & 0.339 \\
\hline PV2 & 0.442 & 0.307 & 0.616 & 0.742 & 0.341 & 0.390 \\
\hline PV3 & 0.555 & 0.484 & 0.514 & 0.829 & 0.178 & 0.387 \\
\hline PV4 & 0.467 & 0.424 & 0.439 & 0.776 & 0.182 & 0.452 \\
\hline PV5 & 0.401 & 0.308 & 0.405 & 0.652 & 0.048 & 0.346 \\
\hline PV6 & 0.476 & 0.473 & 0.479 & 0.707 & 0.080 & 0.356 \\
\hline T1 & 0.102 & 0.056 & 0.273 & 0.236 & 0.885 & 0.126 \\
\hline $\mathrm{T} 2$ & 0.071 & 0.014 & 0.247 & 0.204 & 0.894 & 0.117 \\
\hline T3 & 0.111 & 0.059 & 0.291 & 0.273 & 0.951 & 0.149 \\
\hline $\mathrm{T} 4$ & 0.047 & 0.019 & 0.193 & 0.168 & 0.902 & 0.062 \\
\hline T5 & 0.065 & 0.002 & 0.246 & 0.185 & 0.905 & 0.103 \\
\hline T6 & 0.031 & 0.039 & 0.171 & 0.157 & 0.858 & 0.093 \\
\hline
\end{tabular}

\begin{tabular}{|c|c|c|c|c|c|c|}
\hline T8 & 0.035 & 0.040 & 0.254 & 0.188 & 0.827 & 0.105 \\
\hline T9 & 0.088 & 0.066 & 0.244 & 0.246 & 0.746 & 0.150 \\
\hline SMM1 & 0.320 & 0.311 & 0.275 & 0.356 & 0.044 & 0.741 \\
\hline SMM2 & 0.381 & 0.378 & 0.274 & 0.433 & 0.116 & 0.806 \\
\hline SMM3 & 0.230 & 0.176 & 0.301 & 0.307 & 0.300 & 0.669 \\
\hline SMM4 & 0.294 & 0.376 & 0.222 & 0.356 & -0.005 & 0.697 \\
\hline SMM5 & 0.356 & 0.318 & 0.464 & 0.500 & 0.154 & 0.792 \\
\hline SMM6 & 0.338 & 0.143 & 0.343 & 0.332 & 0.139 & 0.694 \\
\hline SMM7 & 0.210 & 0.183 & 0.216 & 0.263 & 0.030 & 0.726 \\
\hline SMM8 & 0.232 & 0.256 & 0.314 & 0.329 & 0.099 & 0.673 \\
\hline SMM9 & 0.329 & 0.264 & 0.228 & 0.298 & -0.009 & 0.621 \\
\hline
\end{tabular}

Source : Primary data processed (2021)

In addition, discriminant validity testing can also be performed by comparing fornell-larcker criteria. Good discriminant validity is indicated from the Fornell-Larcker Criterion for any construction greater than the correlation between constructions in the model (Ghozali, I., Latan, 2015). The cross-loading values between constructions can be seen as follows: 
Table 4. Discriminant Validity Test with Fornell-Larcker Criteria

\begin{tabular}{|c|c|c|c|c|c|c|}
\hline & $\begin{array}{c}\text { Students' } \\
\text { Decision }\end{array}$ & Motivation & $\begin{array}{c}\text { Perceived } \\
\text { Quality }\end{array}$ & $\begin{array}{c}\text { Perceived } \\
\text { Value }\end{array}$ & Religiosity & $\begin{array}{c}\text { Social } \\
\text { Media } \\
\text { Marketing }\end{array}$ \\
\hline Student's Decision & $\mathbf{0 . 8 3 9}$ & & & & & \\
\hline Motivation & 0.576 & $\mathbf{0 . 7 6 9}$ & & & & \\
\hline Perceived Ouality & 0.438 & 0.333 & $\mathbf{0 . 7 6 0}$ & & & \\
\hline Perceived Value & 0.627 & 0.545 & 0.663 & $\mathbf{0 . 7 4 7}$ & & \\
\hline Trust & 0.085 & 0.046 & 0.282 & 0.247 & $\mathbf{0 . 8 7 3}$ & \\
\hline $\begin{array}{c}\text { Social Media } \\
\text { Marketing }\end{array}$ & 0.428 & 0.384 & 0.418 & 0.506 & 0.135 & $\mathbf{0 . 7 1 5}$ \\
\hline
\end{tabular}

Source : Primary data processed (2021)

The next outer model evaluation is a reliability test that can be done by measuring two criteria, namely composite reliability and Cronbach' Alpha whose value should be above 0.7 , so that a construction can be said to be reliable. The results of composite reliability tests and Cronbach' Alpha show that all constructions have values above 0.7 as presented in table 2 in advance.

\section{Inner Model Evaluation}

Evaluation of the Inner Model or structural model aims to predict causality relationships between latent variables based on the proposed model. In pls-sem research, structural model evaluation was conducted by looking at the value of the coefficient of determination $\left(\mathrm{R}^{2}\right)$, the predictive relevance of $\mathrm{Q}^{2}$, and also the Goodness of fit $(\mathrm{GoF})$ index.

First by looking at the magnitude of the variance presentation described in the R2 value for endogenous latent construction. The $\mathrm{R}^{2}$ assessment criteria can be classified into three, i.e. the $R^{2}$ value is 0.67 which indicates that the model is strong, the $R^{2}$ value is 0.33 which indicates that the model is medium, and the $\mathrm{R}^{2}$ value is 0.19 which indicates that the model is weak (Haryono, 2017). The $\mathrm{R}^{2}$ values in endogenous latent variables in this study can be seen in table 5 below.

Table 5. Value of R-Square

\begin{tabular}{|c|c|c|}
\hline Variabel & R Square & R Square Adjusted \\
\hline Perceived Value & 0.589 & 0.579 \\
\hline Student's Decision & 0.482 & 0.465 \\
\hline
\end{tabular}

Source : Primary data processed (2021)

Based on the $\mathrm{R}^{2}$ value in table 5 above, it can be seen that the $\mathrm{R}^{2}$ value in the perceived construction value is 0.589 , and the student decision construction is 0.482 . This indicates that the variable value is felt relatively strongly because the value is close to 0.67 , while the construction of student decisions is moderate because the value is close to 0.33 . Next evaluation by testing the predictive relevance of $Q^{2}$ to measure how well the observation value is generated by the model as well as the approximate parameters. In its assessment, the $\mathrm{Q}^{2}>0$ value indicates that the model has predictive relevance, and if the $\mathrm{Q}^{2}<0$ value indicates that the model has no predictive relevance (Ghozali, I., Latan, 2015). The results of the $\mathrm{Q}^{2}$ predictive relevance test show that the two endogenous variables in this study have good predictive relevance which can be seen as follows. 
Table 6. Value of Q-Square

\begin{tabular}{|c|c|c|c|}
\hline & SSO & SSE & $\mathbf{Q}^{2}$ (=1-SSE/SSO) \\
\hline Perceived Quality & 790.000 & 790.000 & \\
\hline Motivation & 948.000 & 948.000 & \\
\hline Social Media Marketing & 1.422 .000 & 1.422 .000 & \\
\hline Trust & 1.264 .000 & 1.264 .000 & \\
\hline Perceived Value & 948.000 & 652.460 & $\mathbf{0 . 3 1 2}$ \\
\hline Student's Decision & 632.000 & 434.598 & $\mathbf{0 . 3 1 2}$ \\
\hline
\end{tabular}

Source : Primary data processed (2021)

The final step to evaluating the inner model is to use the Goodness of Fit Index $(\mathrm{GoF})$, which is used to evaluate structural models and overall measurement models, with the criteria $\mathrm{GoF}=0.10$ of a small value, $\mathrm{GoF}=0.25$ of a medium value, $\mathrm{GoF}=0.36$ of a large value. The result of goodness conformity can be determined through the following calculations:

$$
\begin{aligned}
& \text { GoF }=\sqrt{\overline{A V E} \times \overline{R^{2}}} \\
& =\sqrt{0,6175 \times 0,5355} \\
& =0,5750
\end{aligned}
$$

Based on the calculation results, a value of 0.575 can be determined because this research model has a large GoF index. This explains the research data according to the research model.

\section{HYPOTHESIS TEST}

After evaluating the outer model and inner model, the next step is hypothesized testing based on the evaluation of the inner model or structural model that has been obtained in the table below by looking at the t-statistical value as well as the $p$ value. Criterion, if the statistical value $t$ is greater than 1.96, and the $p$ value is less than 0.05 at a significant rate of $5 \%$, then the hypothesis is accepted, or in other words there is an influence between exogenous variables on endogenous variables in each hypothesis has

\begin{tabular}{|c|c|c|c|c|c|}
\hline & $\begin{array}{c}\text { Original } \\
\text { Sample }(0)\end{array}$ & $\begin{array}{c}\text { Sample } \\
\text { Mean (M) }\end{array}$ & $\begin{array}{l}\text { Standard } \\
\text { Deviation } \\
\text { (STDEV) }\end{array}$ & $\begin{array}{r}\text { T Statistics } \\
(|O / S T D E V|)\end{array}$ & $P$ Values \\
\hline $\begin{array}{l}\text { Perceived Quality } \rightarrow> \\
\text { Perceived Value }\end{array}$ & 0.459 & 0.458 & 0.063 & 7.299 & 0.000 \\
\hline $\begin{array}{c}\text { Perceived Quality } \rightarrow \text { Student's } \\
\text { Decision }\end{array}$ & 0.053 & 0.053 & 0.099 & 0.534 & 0.593 \\
\hline Motivation $\rightarrow$ Perceived Value & 0.320 & 0.319 & 0.067 & 4.802 & 0.000 \\
\hline $\begin{array}{c}\text { Motivation } \rightarrow \text { Student's } \\
\text { Decision }\end{array}$ & 0.314 & 0.320 & 0.083 & 3.763 & 0.000 \\
\hline $\begin{array}{l}\text { Social Media Marketing- } \\
\quad>\text { Perceived Value }\end{array}$ & 0.181 & 0.185 & 0.067 & 2.690 & 0.007 \\
\hline $\begin{array}{c}\text { Social Media Marketing -> } \\
\text { Student's Decision }\end{array}$ & 0.098 & 0.098 & 0.083 & 1.180 & 0.239 \\
\hline Trust $\rightarrow$ Perceived Value & 0.078 & 0.084 & 0.054 & 1.442 & 0.150 \\
\hline $\begin{array}{c}\text { Trust } \rightarrow>\text { Student's } \\
\text { Decision }\end{array}$ & -0.052 & -0.046 & 0.073 & 0.710 & 0.478 \\
\hline $\begin{array}{c}\text { Perceived Value } \rightarrow \text { Student's } \\
\text { Decision }\end{array}$ & 0.384 & 0.375 & 0.103 & 3.717 & 0.000 \\
\hline
\end{tabular}
been proposed.

Table 7. Path Coefficient and Significance

Source : Primary data processed (2021) 
AKSARA: Jurnal Ilmu Pendidikan Nonformal

P-ISSN 2407-8018 E-ISSN 2721-7310 DOI prefix 10.37905

Volume 07, Issue 03 September 2021

http://ejurnal.pps.ung.ac.id/index.php/Aksara

\section{DISCUSSION}

\section{The Effect of Perceived Quality on Perceived Value}

Based on hypothesis testing, it was shown that perceived quality construction had a positive influence on the construction of perceived values as indicated by the coefficient of line 0.459 . In addition, the perceived quality and construction relationship of the perceived value is significant because it has a statistical value of $t$ 7,299 greater than the value of t-table (1.96), and also a value of $\mathrm{p} 0.000$ smaller than 0.5. So $\mathrm{H}_{1}$ is supported. This research is in accordance with the Means-End Model theory developed by (Zeithaml, V., 1988) on the relationship between price, quality, and value, which states that perceived quality can directly affect the perceived value. The results of this study also support the results of previous research conducted by Hapsari, R. Cl. \& D. (2016) and H. S. Chen et al. (2017) findings in this study and also some previous studies reinforce the theory that perceived quality has a significant positive influence on perceived values. The positive influence shows that the higher the quality students feel, the higher the value students feel towards vocational higher education institutions.

\section{The Effect of Perceived Quality on Student Decisions}

The second hypothesis test showed that the construction of perceived quality did not have a significant influence on students' decisions in choosing a course of study at a Vocational Higher Education institution. This is evidenced by the path coefficient value 0.053 , and also the t-statistical value 0.534 which is smaller than 1.96 , and the $\mathrm{p}$ value 0.593 greater than 0.05 . Therefore, $\mathrm{H}_{2}$ is not supported. This study is contrary to previous research Hapsari, R. Cl. \& D.(2016) which found that perceived quality had a positive influence on purchasing decisions. Nevertheless, this study is in accordance with the means-end model theory developed by Zeithaml, V. (1988), in which the theory explains that perceived quality must pass the perceived value to influence consumer purchasing decisions. In addition, H. S. Chen et al. (2017) explained in their research that the perceived quality of consumers needs to go through the perceived value of consumers to influence purchasing intentions.

\section{The Influence of Motivation on Perceived Values}

The third hypothesis test showed that building motivation had a positive influence on the perceived value as evidenced by the coefficient of the 0.320 path. The relationship between motivational construction and perceived value is significant because it has a statistical value of $t$ greater than 1.96, which is 4,802, and has a value of $p 0.000$ which is smaller than 0.05 . Based on the data, $\mathrm{H}_{3}$ is supported. The higher the motivation of students to study at vocational higher education institutions, the higher the perceived value student. Building motivation in this study included intrinsic motivation and extrinsic motivation. The results of this study support the results of previous research conducted by Wang, X. L., Chia (2015), Prebensen et al.(2013) which found that motivation has a positive influence on perceived values.

\section{The Influence of Motivation on Student Decisions}

The results of hypothesis testing in this study showed that building motivation has a positive influence on students' decisions in choosing a course of study at Vocational College, as evidenced by the coefficient of line 0.314. In addition, the relationship 
between building student motivation and decisions proved significant with a statistical score of 3,763 greater than 1.96 and a p 0.000 value of less than 0.05 , so $\mathrm{H}_{4}$ was supported. Based on the positive influence between the two constructions, it can be said that the higher the motivation of prospective students, the higher their willingness to choose Vocational Higher Education. The results of this study are in line with previous studies conducted by Rizqiah \& P., Ratna (2017), Lusia, A., Suciati, P., Setiowati (2016) and Handayani (2019) who found that the motivation had a positive and significant impact on students' decisions in choosing higher education institutions. In addition, research conducted by Gunawan (2018) found that motivation has a significant influence on consumer purchasing decisions.

\section{The Impact of Social Media Marketing on Perceived Value}

Subsequent hypothesis testing showed that social media marketing construction had a positive influence on the perceived value as evidenced by the path coefficient value of 0.181 . The relationship between the construction of social media marketing and the perceived value is significant because it has a statistical value of t 2,690 greater than 1.96, and a value of $\mathrm{p} 0.007$ which is less than 0.05 . Thus, $\mathrm{H}_{5}$ is supported. This explains that the better and more precise social media marketing strategies undertaken by Vocational Higher Education, further increase the value students feel towards vocational higher education to be chosen. The results of this study are in line with the findings of a previous study conducted by S. C. Chen \& Lin (2019) which stated that there is a positive and significant influence between social media marketing on perceived value. This research is also in line with a similar study conducted by Serawati (2019) which found that social media marketing affects consumer perception. Likewise in a study conducted by Khan (2019) which found that social media marketing has an influence on value awareness.

\section{The Influence of Social Media Marketing on Student Decisions}

Further hypothesis test results in this study showed a positive but insignificant relationship between social media marketing and students' decision to choose a course of study at a Vocational Higher Education institution, as evidenced by the coefficient of line 0.098 . The statistical value $t$ smaller than 1.96 is 1.180 , and the $p$ value is $0.239>0.05$, which indicates the relationship between the two constructions is insignificant. As such, $\mathrm{H}_{6}$ is not supported. The results of this study are not in line with the results of previous research conducted by Nurohman, Y.A. \& Qurniawati (2018) which found that social media promotion has a positive influence on the choice of study programs.

Although the results of this study are contrary to the previous studies mentioned above, there are several other studies that are in line with the results of this study. Balakrishnan, et al (2014) found that there was no significant effect between social media marketing on purchasing intentions. Another similar study conducted by Hapsari, R. Cl. \& D. (2016) showed that social media had no significant impact on students' decisions in choosing higher education institutions. This can be due to the lack of involvement of university management such as the Public Relations Division and Marketing Division in responding to or interacting with social media users, as well as a lack of interesting and innovative content. 


\section{The Influence of Trust on Perceived Values}

Subsequent hypothesis testing showed results that trust construction had a positive but insignificant influence on the construction of perceived value. This is evidenced by the path coefficient 0.078 , but the t-statistical value of 1.442 is smaller than 1.96 , and the $\mathrm{p}$ value 0.150 is greater than 0.05 . As such, $\mathrm{H}_{7}$ is not supported. Basically, there is very limited research available that discusses the correlation between belief and perceived value. Empirically, the results of this study are contrary to the results of research conducted by Rizqiah \& P., Ratna, (2017) which states that trust has a positive influence on the value felt by customers. Based on the results of this study, it can be stated that the value that students feel about Vocational Higher Education is not influenced by individual beliefs. This is because the perceived value is the overall consumer assessment of the utility of the product based on the perception of what is received and what is given based on the comparison between benefits and sacrifices. So, in this case, trust measured from the dimensions of faith and behavior and worship has nothing to do with a consumer's general assessment of the benefits of a product or service with respect to what is provided and what is received in return.

\section{The Influence of Trust on Student Decisions}

In hypothesis testing in this study showed that building trust has a negative relationship with the construction of student decisions as evidenced by the coefficient value of the line -0.052 . In addition, the relationship between the two constructions was also declared insignificant because it has a t-statistical value of less than 1.96 which is 0.710 , and a $\mathrm{p}$ value greater than 0.05 , which is 0.478 . Based on the results, $\mathrm{H}_{8}$ is not supported. The results of this study do not empirically support some previous research conducted by Ilgan, A., Ataman, O., Ugurlu, F., Yurdunkulu (2018) which states that trust has a positive and significant impact on consumer interest and purchasing decisions. This is due to the difference in the nature of the object of this study with previous research, namely banks and universities, where the selection of higher education institutions is not influenced by halal-haram considerations, so students are more likely to choose based on the quality or value obtained.

\section{The Effect of Perceived Value on Student Decisions}

In the latest hypothesis testing showed that the perceived value had a positive influence on students' decisions in choosing a course of study in Vocational Higher Education. This is evident from the coefficient value of the path held by 0.384 . In addition, the relationship between building perceived grades and student decisions proved significant, as it had a statistical score of $\mathrm{t} 3,664$ greater than 1.96, and a $\mathrm{p}$ value of 0.000 that was less than 0.05 . Thus, $\mathrm{H}_{9}$ is supported. The positive influence in the findings of this study shows that the higher the value students feel towards Vocational Higher Education institutions, the higher the willingness to choose Vocational Higher Education.

The results of this study are in line with previous research conducted by Serawati (2019) which found that the perceived value has a positive influence on purchasing decisions. In addition, research conducted by S. C. Chen \& Lin, (2019) found that perceived value has an important mediation role in the indirect influence of perceived quality and risk on purchasing intentions. In line with the study, Nguyen (2014) also 
found that the perceived value has a positive and significant effect on purchasing intentions.

\section{CONCLUSION}

Based on the above analysis and discussion, the conclusions of the results of this study can be summarized as follows: (1) The perceived quality has a positive and significant influence on the perceived value, which means that the higher the perceived quality, the higher the value felt by students. (2) The perceived quality does not have a significant influence on student decisions, which means that the high quality of Vocational Higher Education will not necessarily affect students' decisions in choosing a Higher Education. This is because the perceived quality needs to pass the perceived value to influence student decisions. (3) Motivation has a positive and significant influence on perceived value, which means that the higher the student's motivation, the better the student's perceived value. (4) Motivation has a positive and significant influence on student decisions, which means the higher the motivation possessed by students, the higher the willingness to choose Vocational Higher Education institutions. (5) Social media marketing has a positive and significant effect on perceived value. This shows that the better the social media marketing strategy used, the higher the value felt by students. (6) Social media marketing does not have a significant influence on student decisions, which means that social media marketing is not enough to influence students' decisions in choosing Vocational Higher Education institutions, but it is necessary to go through perceived value variables. (7) Trust has no significant influence on perceived value. (8) Trust has no significant influence on student decisions, otherwise it has a negative relationship. (9) The perceived value has a significant influence on student decisions. This means that the higher the score felt by students towards Vocational Higher Education, the higher their willingness to choose Vocational Higher Education.

\section{RECOMMENDATIONS}

This research offers several recommendations that allow vocational higher education marketing practitioners in Banten Province, even in Indonesia generally, to develop and design effective marketing strategies to recruit new students. Vocational Colleges must conduct periodic and continuous evaluation of quality perceptions, especially prospective students of their institutions, so as to improve the quality of Vocational Higher Education felt. Some ways that can be done is by improving the quality and competence of lecturers, as well as providing high-quality learning facilities and facilities, in order to increase the value felt by prospective students so that it will influence their decision to choose a College or Vocational University. Vocational Higher Education Institutions need to develop marketing strategies that aim to motivate prospective students, both in terms of intrinsic motivation and extrinsic motivation. This can be done by creating educational content or articles in various promotional media such as official institutional websites or blogs, social media, or also creating guest posts on online news portals and print media publications, with content that encourages or motivates prospective students, such as the importance of having professional skills and skills to be able to compete in the world of work, provide scholarships, and so on. In addition, Vocational Higher Education institutions need to create engaging social media content on social media platforms such as Facebook, Instagram, and YouTube and maintain 
relationships with prospective students with interactive and fast social media admins, which is a big challenge for marketers of these institutions.

\section{LIMITATIONS}

This study faces some limitations. The main limitation is that the data is collected in hybrid form: direct responses and online responses because the data was collected in the middle of the coronavirus pandemic. According to Al-Salom (2019), participants in online data collection may not contribute valid data, especially in stressful life events such as the Covid-19 pandemic. This data collection procedure may affect the validity of the facts provided by the respondent.

\section{REFERENCE}

Chen, H. S., Tsai, B. K., \& Hsieh, C. M. (2017). Determinants of consumers' purchasing intentions for the hydrogen-electric motorcycle. Sustainability (Switzerland), 9(8), 1-12. https://doi.org/10.3390/su9081447

Chen, S. C., \& Lin, C. P. (2019). Understanding the effect of social media marketing activities: The mediation of social identification, perceived value, and satisfaction. Technological Forecasting and Social Change, 140(November 2018), 22-32. https://doi.org/10.1016/j.techfore.2018.11.025

Fauzi, W. I. M., Nazlida, M., Sany, S. M. Y., Rushamie, Z. (2016). What motivate muslim consumer to patronage islamic based-retail store? International Review of Management and Marketing, 6(7Special Issue), 199-203.

Ghozali, I., Latan, H. (2015). Partial least squares konsep, teknik dan aplikasi menggunakan program smartpls 3.0 untuk penelitian empiris. Semarang: Badan Penerbit UNDIP.

Gunawan, W. (2018). Peluang Usaha Pengembangan Bebek Peking. THL TBPP Cianjur. Handayani, F. (2019). POTENSI PANGSA PASAR PERGURUAN TINGGI SWASTA DI INDONESIA [Studi Pada Universitas Islam Syekh-Yusuf Tangerang]. Jurnal Penelitian Dan Karya Ilmiah, 19(2), 114-139. https://doi.org/10.33592/pelita.vol19.iss2.116

Hapsari, R. Cl., M., \& D., and D. (2016). The Mediating Role of Perceived Value on the Relationship between Service Quality and Customer Satisfaction: Evidence from Indonesian Airline Passengers. Procedia Economics and Finance, 35(October 2015), 388-395. https://doi.org/10.1016/s2212-5671(16)00048-4

Harjati, L., \& Sabu, O. (2014). Produk Terhadap Keputusan Pembelian The Body Shop. E-Journal WIDYA Ekonomika, 1(November).

Haryono, S. (2017). Metode SEM untuk Penelitian Manajemen AMOS Lisrel PLS. Jakarta: Luxima Metro Media.

Ilgan, A., Ataman, O., Ugurlu, F., Yurdunkulu, A. (2018). Factors Affecting University Choice : A Study on University Freshman Students. The Journal of Buca Faculty of Education, December 2018, Issue 46, p. 199-216, 46, 199-216.

Kandasamy, C. (2014). Impact of customer brand perceived quality on buying intention of durable products-A customers view. International Journal of Management and Social Science Research Review, 1(3), 1-5.

Khan, M. M. (2019). The Impact of Perceived Social Media Marketing Activities: An 
Empirical Study in Saudi Context. International Journal of Marketing Studies, 11(1), 134. https://doi.org/10.5539/ijms.v11n1p134

Kurnianto, D. (2015). Perceived Quality, Perceived Value, Perceived Sacrifice Dan Pengaruhnya Terhadap Customer Satisfaction (Survei Pada Pengguna Jasa Bus Efisiensi).

Lusia, A., Suciati, P., Setiowati, E. (2016). Motivasi Intrinsik Yang Mempengaruhi Pemilihan Jurusan Dan Universitas (Studi Pada Mahasiswa Baru Program Vokasi Universitas Indonesia Angkatan 2015). Jurnal Vokasi Indonesia, 3(2). https://doi.org/10.7454/jvi.v3i2.31

Nguyen, G. A. (2014). Factors that influence consumer purchasing decisions of Private Label Food Products A case study of ICA Basic. Factors That Influence Consumer Purchasing Decisions of Private Label Food Products, 25, 42-43.

Nurohman, Y.A., Qurniawati, R. S. (2018). Peran Promosi Media Sosial Pada Pemilihan Program Studi Manajemen Bisnis Syariah. Among Makarti Vol.11 No.22, Desember 2018, 11(22), 62-76.

Prebensen, N. K., Woo, E., Chen, Joseph, S., \& Uysal, M. (2013). Motivation and Involvement as Antecedents of the Perceived Value of the Destination Experience. Journal of Travel Research, 52(2), 253-264. https://doi.org/10.1177/0047287512461181

Rizqiah, R., \& P., Ratna, N. Y. (2017). Hubungan Motivasi Mahasiswa Dengan Minat Dalam Memilih Jurusan Tadris Ilmu Pengetahuan Sosial. Jurnal Edueksos, VI(1), $1-20$.

Rudhumbu, N., Tirumalai, A., Kumari, B. (2017). Factors that Influence Undergraduate Students' Choice of a University: A Case of Botho University in Botswana. International Journal of Learning and Development, 7(2), 27. https://doi.org/10.5296/ijld.v7i2.10577

Ryan, R. M. D., Edward, L. (2000). Intrinsic and Extrinsic Motivations: Classic Definitions and New Directions. Contemporary Educational Psychology, 25(1), 54 67. https://doi.org/10.1006/ceps.1999.1020

Serawati, F. M. (2019). Pengaruh Harga Dan Perceived Value Terhadap Keputusan Pembelian Smartphone Oppo. PROGRAM STUDI EKONOMI SYARIAH FAKULTAS EKONOMI DAN BISNIS ISLAM INSTITUT AGAMA ISLAM NEGERI (IAIN) BENGKULU.

Tuten, T. S., Michael, R. (2017). Social Media Marketing. In University of International Business and Economics International Summer School (Vol. 1, Issue 1, pp. 1-7). Pearson/Prentice Hall.

Wahyuni, D. U. (2008). Pengaruh Motivasi, Persepsi Dan Sikap Konsumen Terhadap Keputusan Pembelian Sepeda Motor Merek "Honda" Di Kawasan Surabaya Barat. Jurnal Manajemen Dan Kewirausahaan, 10(1), 30-37-37. https://doi.org/10.9744/jmk.10.1.pp.30-37

Wang, X. L., Chia, H. (2015). A Study of Tourism Motivation, Perceived Value and Destination Loyalty for Macao Cultural and Heritage Tourists. International Journal of Marketing Studies, 7(6), 83. https://doi.org/10.5539/ijms.v7n6p83

Zeithaml, V., A. (1988). Consumer Perceptions Of Price, Quality, And Value : A MeansEnd Model and Synthesis of Evidence. Journal Of Marketing, 52(3), 2-22. 